Hemaloshinee Vasudevan,

Dr.Sc., Inti International University, Malaysia

(iD ORCID ID, 0000-0002-2767-8044

email: hemaloshinee25@.gmail.com

Imran Aslan,

Associate Professor, Bingol University, Turkey

(iD) ORCID ID, 0000-0001-5307-4474

email: imranaslan@gmail.com

Correspondence author: hemaloshinee25@gmail.com

\title{
COSMETOLOGY ADVERTISING PERSPECTIVES: APPLICATION OF ETHICAL THEORIES DURING COVID-19 CRISIS
}

Abstract. In a pandemic, there are no egalitarians because all citizens cannot treat equally, and a failure to consider ethical concerns before taking action led to a massive and preventable loss of life. As a result of the pandemic, there is a strong ethical or moral imperative to consider how to help the most generous people usage healthy products. Utilitarianism and Kantian have become popular ethical theories that state the right actions that layout clear and actionable principles. This paper reviews (1) how Utilitarianism and Kantianism theories could produce benefit arguments on ethical purchases of cosmetic products from an advertising context, (2) how these theories contributed in the context of COVID-19 to help reduce any harmful health issues via advertising, and (3) Utilitarianism and Kantian theories have proven useful during the COVID-19 pandemic, according to case studies of cosmetics products and advertising in Western and Asian contexts. In addition to these two ethical theories, this paper discussed other issues. The purpose is not to argue which theory is the only relevant ethical theory but to contend with pure utilitarianism. Kantian's finding was similar to the topic argument in other ways. However, both theories reviewed as the most effective way to help societies identify and perceive the necessary costs of goods values. Before adopting utilitarian or Kantian theories, the community must clearly understand these two theories' merit values in product advertising. In such a crisis, ethical theories practices should implement in all areas because ethical challenges would determine whether or not advertisers around the world adhered to ethical standards in devising new and innovative marketing strategies, practices, or tactics for the transition to this new norm.

Keywords: cosmetics advertising, COVID-19, cosmetics product, Kantian theory, utilitarian theory.

Introduction. A long-standing debate has raged over the proper role of ethics in social sciences and humanities. Concerning the appropriate role ethics should play in forming people's habits, advertising, in particular, and marketing in general, are not dissimilar. Consumers' ethical perceptions and habits have been the subject of numerous academic papers. However, in this academic paper, the researcher has taken a unique approach by relating Utilitarian and Kantian ethical theories to purchasing behavior from the perspective of cosmetology advertising during this pandemic. The unique circumstances surrounding the COVID-19 pandemic and other factor considerations should be considered besides utilitarian and hedonic motives such as Kantianism ethics perspective. Media coverage of the pandemic has been extensive during the crisis, and consumers expose to a great deal of information about the current economic situation (Loxton et al., 2020). The author considers Kant's theory because it focuses not only on what people could do or what rules they must follow to be ethical and moral but also on their intention to do the right thing. Kant also defines the preservation of reason as ethical action that is reasonable and logical. It is independent of desires, consequences, and benefits (Kant and Wood, 2009). Perhaps Utilitarian and Kantian ethics (Martin et al., 2021) behavioral intentions (Abdullahi, 2018) in advertising are typically used to analyze positive consumer purchasing behavior (Amaro and Duarte, 2015) and make a

Cite as: Vasudevan, H., \& Aslan, I. (2021). Cosmetology Advertising Perspectives: Application of Ethical Theories During COVID-19 Crisis. Marketing and Management of Innovations, 4, 121-136. http://doi.org/10.21272/mmi.2021.4-10 
decision appropriately to reduce the harmful health issue from the perspective of cosmetology advertising (Abdullahi, 2018) during COVID-19 crisis. Besides this, the dilemma of deception in advertising is crucial to the public's perception of the industry's integrity and logicality. When a person's ethical purchasing behavior is active rather than passive, materialism has less of an impact on their intentions (Bakar et al., 2013). In general, how have advertisers contributed to the well-being and development of the communities where they operate? In this way, advertising messages promote altruistic motives such as social harmony, honesty, and integrity in business relationships and adhering to ethical practice (Olatunji, 2013) in the marketplace. It's important because it relates to advertising ethics in a materialistic and greed-driven society. As a result of this pandemic, cosmetology advertising could provide a thorough explanation by applying Utilitarian and Kantian ethical theories.

Utilitarian ethical theory value is a strengthened and more stringent moral reason to omit to do benefit than to harm. It's meant to avoid making things worse (Savulescu et al., 2020) and detriment the consumer by providing fake advertising to the cosmetic products and spoiling consumers' behavioral intention (Sripathi, 2020; Nuseir, 2018; Nejati and Moghaddam, 2013; Chiu et al., 2014) in purchasing the cosmetics product by sensible advertising. Recent studies (Koch et al., 2020) on consumer behavior during the COVID-19 pandemic confirm this approach and show that the pandemic affects consumers' decisionmaking and behavior intention. But in terms of Kantian ethical perspective, cosmetology advertising encompasses a wide range of important aspects and categories (for example, the ethicalness of advertised products, employee treatment, managerial decisions, and the honesty of the advertisements) during this pandemic. In marketing business ethics, Kant's theory is crucial because it dissociates ethical behavior from the expectation of certain returns and underlying motives. Instead, it suggests that perceived moral actions are based on goodwill and pure rationality. Alternatively, the researcher argued that a society without moral principles would end up in ruins because people do not understand what morality (right/wrong) consists of (Podrez, 2017). In this case, ethical advertising is vital for cosmetic products containing inorganic materials that have become more commonplace, and consumers are more aware of their harmful effects (Al Mamun et al., 2018; Rani and Krishnan, 2018). According to Fardouly et al. (2017), women's physical and mental health (self-confidence and self-awareness) have been negatively affected by idealized media (advertising) images in recent years. Idealized advertising images could also lead consumers to try to achieve unattainable standards for their bodies through unrealistic expectations (Arendt et al., 2017) when the consumer makes a purchase decision without considering the potential harm. The Utilitarianism and Kantian ethical theories lead some consumers to adopt a perfect buying behavior by identifying quality and harmless cosmetic products with good content advertising. Thus, Utilitarianism theory should apply in cosmetology advertising due to well-being, protect rights, promote equality and happiness in the world during this COVID-19 pandemic. According to Kant's theory, social well-being (Sasa, 2019) is promoted for all moral issues. Kant drew attention to the perspective, approach, and motive people should evaluate ethical issues. As a result of Kant's ethical dilemma, ethics should not be affected by external factors such as monetary gain or gain in emotional or other terms. Ethics should not be motivated by self-interest, including a desire to feel good about the ethical action you are committing. Therefore, the act was not morality in terms of cosmetology advertising during the COVID-19.

Based on both theories (Utilitarianism and Kantian), the latest study (Khattri, 2019) found that cosmetology advertising contributes causally to physical well-being $(X u, 2020)$ through the use of skincare products. COVID-19 pandemic had a significant impact on individuals' psychosocial and physical health, according to cosmetology advertising (Yildirim and Güler, 2020). Advertisers should reflect a set of attributes before publishing any information, not just those that feature beautiful images and the contents of the cosmetic products. An alternative is to examine their options and weigh the costs by applying ethical standards. As a substitute for Kantian theory, utilitarianism is better to start. 
Literature Review. Based on happiness and pleasure, utilitarian theory derives its true morality from its contribution to humans and non-humans. As a result of animal suffering, there is a wide range of opinions on the use of animals in cosmetology. Because they are the owners of the animals, those who support animal rights activists must protect them from suffering. For at least some moral standing, the capacity for pain is sufficient by itself. The ability to feel pain is sufficient in and of itself to confer at least some moral standing. In addition, the animals' overall well-being is crucial. Animal activists want to ban the use of rabbits in the cosmetics industry and the raising of chickens for the market in chemical and biochemical tests. In Australia, the Cruel-Free Campaign provided with a fair trademark. Concerning the environment, fairtrade symbols could increase profits for businesses. As a result of ethical concerns, fairtrade cosmetics are more expensive for cosmeticians to purchase (Wang et al., 2020). Cosmetics users are classified as ethical consumers able to reduce eye irritation in mice, monkeys, and dogs. It attracts ethical consumers by offering environmentally friendly products that have not been tested on animals. To promote corporate social responsibility (CSR), cosmetic brands use labels that promote ethical consumerism. The cosmetic industry has applied the Fair Trade Labeling Organization (FLO) and other certification systems to be regarded as ethically developed (Wang et al., 2020).

The COVID-19 outbreak appears in different countries to produce more useful utilitarian ethical purchases (Yang et al., 2020). Since the COVID-19 crisis is a critical period in various countries for all human beings, it would encourage customers and industrials to seek solutions to fix current problems to ensure rapid development in the cosmetics industry in the coming years. Perhaps, it makes it relatively necessary for useful and ethical acquisitions of cosmetic products if people are involved in situations that cause problems to resolve. The ethical value of utilitarianism in advertising business means that advertisers should have an ethnic value to help resolve the question «What advertising actions can ultimately contribute to the increased generosity and viability of most consumers?» (Kim and Ham, 2017). Utilitarianism is an influential moral theory that says that action is morally right to achieve the greatest good. Utilitarianism addresses the consequences, both in terms of increasing the good and reducing the harm. The utilitarian ethical theory applies in the present crisis to explain cosmetic products and how advertising could influence human rights or actions to obtain quality products rather than advertisements that could damage the choice of customers. Halim et al. (2020) said the analysis of cosmetic or beauty advertising should be carried out to allow consumers to engage more closely in beauty advertising and provide the language tools to retrieve product claims in advertising. It enables us to examine how consumers can challenge the utilitarian approach through the debate on beauty advertising. In previous studies (Hackley et al., 2021; Dahlen, 2018), consumers are not keen to receive push advertising messages because they prefer seeking information from consumers who want to advertise directly from individuals rather than brands or products. Due to the COVID-19 crisis, morally entitled to choose customers did not wish to make a harmful decision. Based on the advertising perspectives, the utilitarian theory could consider communications in cosmetic products as ads to reach the desired goals for consumers' content and satisfaction. An approach of utilitarianism is applied in advertising because advertising restrictions could reduce through consideration of practicality and actuality, the flexible exemption for smooth interactions, and the sharing of the meanings and messages of product with consumers instead of over-complying with rules etc. (Kim and Kim, 2017). The previous study (Scarre, 2020) indicated that the utilitarian theory considers the goal of morality to improve life by increasing good things like happiness and satisfaction, perhaps reducing wrong things like unhappiness and pain. Utilitarianism theory, in this instance, is a truthful morality idea based on its contribution to purchase the cosmetic products by consumers and fulfill the satisfaction of consumers with appropriate advertising messages during this COVID-19 pandemic.

The ethical theory of Kantian is likely to argue for the goodwill of the cosmetics industry, but not at the expense of its stakeholders, competitors, workers, and consumers (Wang et al., 2020). The Kantian theory 
is applicable in this COVID-19 pandemic because the argument contains the rational value (Wang et al., 2020) of natural art and beauty (Skov et al., 2020). The safety of the product advertisements is vital before the production company can produce the products for their consumers. Perhaps safer advertising products ensure the reputation of the company for its customers. Before imposing any advertising during this crisis, cosmetic companies must thoroughly understand the purchasing pattern of the consumer (Anjana, 2018) in terms of product quality, branding, and satisfaction. In this case, advertising creates gratification and pleasure for the brands if the cosmetics manufacturer produces the cosmetic products ethically without harming the consumer's health and body skin.

Based on the Kantian ethical theory, consumers struggle with something ethical or moral because they are not purely rational (Wang et al., 2020). This problem always arises when customers make irrational decisions, and they are very impulsive and can be attracted to advertising activities that affect customers' thinking (Gai, 2020). However, cosmetics advertising affects consumers enormously, and organizations are trying to target irrational consumers who struggle to make ethical decisions when they buy cosmetic products during this crisis. A healthy moral regime should use by all people across the globe when buying cosmetic products during this pandemic, and cosmetic manufacturers must produce highquality cosmetics because of the high chemical dosage in cosmetic products that affect humans' health. With $100 \%$ approval from the Ministry of Health, the cosmetics manufacturing must advertise quality cosmetics products (Mohamed Azmi et al., 2020). The ethical Kantian theory has highlighted that strong morality focuses on humanity and communion among human civilization, maintaining in all walks of human life. The theory also strictly claims that truthful morals are often disregarded as the philosophy does not support business practices that harm ethical people. It is an undertaking that Kantian theory benefits others, and it is also responsible for preventing one's life (Kant, 1999).

From the Kantian stance, it is wrong for industries to seek self-benefits even in advertising cosmetic products because the cosmetics industry has a perfect obligation to secure their capital during this COVID19 risk. From the Kantian perspective, celebrity endorsements advertising gives lesser ethical practices for the cosmetics industry to use celebrity endorsements advertising contents and strategic advertising (Rosenbaum-Elliott, 2021) to promote the cosmetic products due to seek the industry self-benefit in selling and purchasing concepts. Due to the crisis of COVID-19, there is a possible risk in promoting advertising. Researchers' consideration of «risk» does not represent the risk to the marketer or industry to use the endorser. Instead, the study considers the «consumer perceived risk». It should note that perceived consumer risk may relate positively or negatively to perceived market risks, perceived consumer physical risk, perceived risk of product quality, perceived risk of brand value (Jun, 2020), or perceived industrial risks through the use of a cosmetic advertisement endorser (Soesilo et al., 2020). The Kantian ethical theory showed that unethical cosmetic advertising should not be regarded as a self-benefit of the cosmetic industry and should be concerned to prevent human lives (Kant, 1999). It would risk human health by using large doses of chemical cosmetic products.

In terms of Utilitarian and Kantian perspectives, animal testing is required for all cosmetic products imported into the country (Wang et al., 2020). Because the Federal Food, Drug, and Cosmetic Act do not consider whether animal tests should be conducted to ensure the safety of cosmetics for humans, it is illegal for cosmetics that adulterate and mislabeled. As a result of the cosmetic industry's inability to provide happiness, utilitarianism is viewed as a morally deficient philosophy for experimental animals. Nevertheless, Kantian based on the conclusion that some actions are right or wrong is different due to the justification of protecting customers from unknown consequences of cosmetics use. As a result, the use of experimental animals in the cosmetics industry is both ethical and beneficial. The ideal point for these various perspectives is that scientific and humane procedures should be developed in the cosmetics industry while minimizing animal harm (Wang et al., 2020). 
The utilitarian theory derives its true morality from its contribution to humans and non-humans. There are many debates about animal experiments, with some arguing for the use of animals in cosmetology, while others oppose it because of the animals' suffering. People are the owners of the animals, and they have the right to use them, but they also must not cause them suffering and pain. The ability to feel pain is sufficient in itself to confer at least some moral standing. From the perspective of the advertising industry, utilitarianism-based ethical values can consider communication actions in the advertising business as a method to reach the desired goal of consumer «satisfaction» and «happiness». A consumer psychology perspective suggests that utilitarian ethical values are related to the way consumers handle ethical dilemmas when making decisions. The pursuit of mental happiness and desirable results, combined with the satisfaction of consumers' value expectations, makes valuable support for interaction mediating media, implementation of multiple media aiming to maximize communication utility, sharing meaning, and achieving goals using media, such as using one source multi-use. Based on Kantian theory, animal experiments in the cosmetic industry primarily protect the human race. In Kantian theory, the use of animals in the cosmetic industry is morally wrong, regardless of the economic or great pleasure gained from this action utilitarian approach of morality and justice. According to this theory, all moral obligations are universally valid. According to Kantians, animal experiments help determine the safety of products in the cosmetic sector. Animal testing marketing strategy based on Kantian theory highlights that testing animals for cosmetics is not seen as unethical or immoral but as a rational business practice. Based on the fact that animals consider as «subhuman» and that humans have no direct duty towards them. In other words, it was designed to assist humans in their endeavors. As an alternative way, animals use in scientific research, and it has been accepted as a universal law. Although the use of animals to test cosmetic products has not been declared in universal law countries such as China, they can make this claim. Therefore, the vast bulk of cosmetic companies in China will view animal testing as morally acceptable because the Chinese government is also involved in the practice of animal testing. The cosmetic industry appears to be aware of this law and does not consider animal testing unethical. In the eyes of most companies, the practice is rational because other companies also practice it, and there is no universal law that says otherwise (Wang et al., 2020). But from the Kantian perspective, cosmetic products such as shampoo, toothpaste, and women's make-up cannot be tested on animals in the European Union (Thew, 2017). Similarly, in European Union's study, ethical consumers are turning their backs on products that have been animal-tested (Wang et al., 2020). Accordingly, the advertising industry should not base its identity solely on commercial profit-seeking actions based on a micro-practical perspective. Utilitarian and Kantian theory's ethical intention does have some drawbacks. However, it is unclear to whom the majority status indeed granted. It does not consider the goals of marginalized populations, but it can interfere with minorities' happiness and lead to racism and collectivism among cultures with economic or political power. Due to the importance of both utilitarian and Kantian perspectives, a few empirical studies have been conducted in various fields.

Table 1. Empirical Studies

\begin{tabular}{|c|c|c|c|c|c|c|}
\hline \multirow{3}{*}{$\begin{array}{c}\text { Author } I \\
\text { Year }\end{array}$} & \multirow{2}{*}{ Field } & \multicolumn{2}{|c|}{ Utilitarian Theory } & \multicolumn{2}{|c|}{ Kantian Theory } & \multirow{2}{*}{$\begin{array}{c}\text { Business Effects } \\
\text { (Positive / Negative) }\end{array}$} \\
\hline & & Contributed & Non-contributed & Contributed & Non-contributed & \\
\hline & 2 & 3 & 4 & 5 & 6 & 7 \\
\hline $\begin{array}{c}\text { Ulgen } \\
(2017)\end{array}$ & $\begin{array}{l}\text { Artificial } \\
\text { intelligenc } \\
\text { e and } \\
\text { robotics }\end{array}$ & $\begin{array}{l}\text { The use of } \\
\text { autonomous } \\
\text { weapons } \\
\text { based on } \\
\text { cost-benefit } \\
\text { reasoning or } \\
\text { the potential }\end{array}$ & & $\begin{array}{l}\text { Robotics and } \\
\text { artificial intelligence } \\
\text { are two areas } \\
\text { where Kantian } \\
\text { ethics apply. } \\
\text { Kantian ethics: the } \\
\text { categorical }\end{array}$ & $\begin{array}{l}\text { The Kantian notion } \\
\text { eof human dignity } \\
\text { does not treat } \\
\text { humans as mere at } \\
\text { the end. } \\
\text { However, they are } \\
\text { not merely objects }\end{array}$ & $\begin{array}{l}\text { A wide range of } \\
\text { possible applications } \\
\text { and uses for artificial } \\
\text { tintelligence and } \\
\text { robotics technology } \\
\text { could lead to the } \\
\text { emergence of }\end{array}$ \\
\hline
\end{tabular}


Robinson Business

and ShahEnvironme

(2019) ntal

Adekoya Fast Food Promoting Individual justice, and Jimoh antibiotic beneficence, and

(2019) efficacy and autonomy aren't changing always crucial to (potentially act utilitarianism unsafe) toy (Chonko, 2015) batteries because it showed food oppresses an.

Continued Table 1

to save lives

are utilitarian

arguments.

4

imperative, the or things to be competing rules that autonomy of one's handled and used may or may not be

will, rationalism by relative goals universal.

and the rational (e.g., personal

thinking capacity of wants, desires,

rational beings, hopes, and

and human dignity ambitions).

and humanity as

ends in

themselves.

As a rational being

with free will, the

duty to not harm

others is

fundamentally

beneficial to

humanity

The Kantian

exegesis stresses

rational and

reflective public

discourse when it

comes to

environmental

concerns, including

business

obligations.

The Kantian

framework for

environmental duty

relates to business. It

is crucial when it

comes to the

interrelated issues of

the spiritual

contributions of

nature, the

obligations to future

generations, and the

obligations to people

in distant lands.

Business'

contribution to

reasoned social

discourse and the

Kantian philosophy of

duty may allow us to

reach a high degree

of clarity concerning

business'

environmental

responsibilities.

As a result of these

considerations of

utilitarian theory in

the fast-food

industry, people are

more likely to choose

a restaurant that has

a healthy 
Continued Table 1

\begin{tabular}{|c|c|c|c|c|}
\hline 1 & 3 & 4 & 5 & 7 \\
\hline & $\begin{array}{l}\text { quality and } \\
\text { safety, } \\
\text { national } \\
\text { procurement } \\
\text {, suppliers, } \\
\text { and social } \\
\text { accountabilit } \\
\text { y. The } \\
\text { Animal } \\
\text { Welfare } \\
\text { Council and } \\
\text { Global } \\
\text { Principles, } \\
\text { working with } \\
\text { experts, and } \\
\text { animal } \\
\text { welfare } \\
\text { audits are } \\
\text { part of the } \\
\text { animal } \\
\text { welfare } \\
\text { category (De } \\
\text { Blasio, } \\
\text { 2008). }\end{array}$ & $\begin{array}{l}\text { individual to lead a } \\
\text { solution that } \\
\text { benefits most } \\
\text { people }\end{array}$ & & $\begin{array}{l}\text { environment, } \\
\text { including food, the } \\
\text { surrounding, } \\
\text { techniques, and } \\
\text { procedures (Eojina et } \\
\text { al., 2017). } \\
\text { The environmental } \\
\text { category includes } \\
\text { protecting rain } \\
\text { forests, promoting } \\
\text { sustainable fisheries, } \\
\text { raising awareness } \\
\text { about biotechnology, } \\
\text { and decreasing } \\
\text { packaging impact. }\end{array}$ \\
\hline $\begin{array}{l}\text { Wang et al., Animals } \\
2020\end{array}$ & $\begin{array}{l}\text { Increasing } \\
\text { consumer } \\
\text { happiness } \\
\text { and } \\
\text { pleasure }\end{array}$ & $\begin{array}{l}\text { Causing suffering } \\
\text { for animals }\end{array}$ & $\begin{array}{ll}\text { Animals are } & \text { Morally wrong. } \\
\text { subhuman. Always } & \text { Inhuman-making a } \\
\text { being used in } & \text { person cruel to } \\
\text { scientific tests } & \text { other people } \\
\text { Usage in countries } & \\
\text { such as China } & \end{array}$ & $\begin{array}{l}\text { The Fair Trade } \\
\text { Labeling } \\
\text { Organization (FLO) } \\
\text { Ethical consumers } \\
\text { Cruel-Free } \\
\text { Campaign }\end{array}$ \\
\hline $\begin{array}{l}\text { Gordiyevska Digital } \\
\text { ya }(2020) \quad \text { Marketing }\end{array}$ & $\begin{array}{l}\text { To arrive at } \\
\text { a decision, } \\
\text { the author } \\
\text { must weigh } \\
\text { the pros and } \\
\text { cons of the } \\
\text { action. } \\
\text { Utilitarianism } \\
\text { marketing's } \\
\text { goal is to } \\
\text { increase } \\
\text { managers' } \\
\text { understandi } \\
\text { ng that } \\
\text { benefits for } \\
\text { society are } \\
\text { equivalent to } \\
\text { company } \\
\text { profitability. }\end{array}$ & $\begin{array}{l}\text { Incorporate the } \\
\text { marketing strategy } \\
\text { as deeply as } \\
\text { possible into the } \\
\text { business } \\
\text { processes if it will } \\
\text { result in a negative } \\
\text { lattitude from } \\
\text { customers. } \\
\text { Pornographic } \\
\text { material on the } \\
\text { internet appears to } \\
\text { be economically } \\
\text { beneficial, but the } \\
\text { outcome is not } \\
\text { ethical marketing } \\
\text { behavior. }\end{array}$ & & $\begin{array}{l}\text { Increase the } \\
\text { business profitability } \\
\text { and customer } \\
\text { satisfaction in the act } \\
\text { of utilitarian manner. } \\
\text { To avoid the negative } \\
\text { effect on society. } \\
\text { Developing the rights } \\
\text { and benefits by } \\
\text { advertising the } \\
\text { material accordingly. }\end{array}$ \\
\hline
\end{tabular}


Continued Table 1

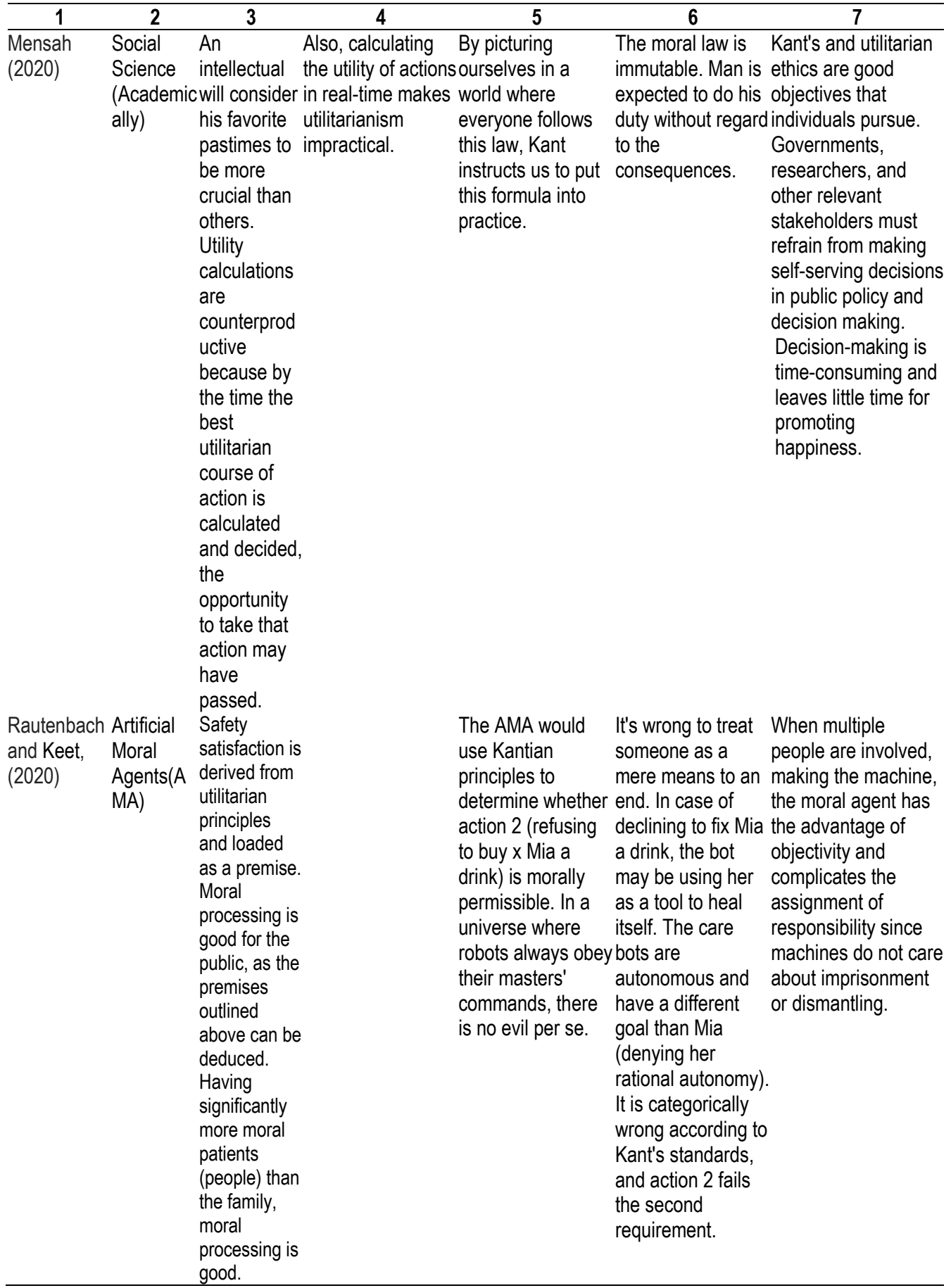


Continued Table 1

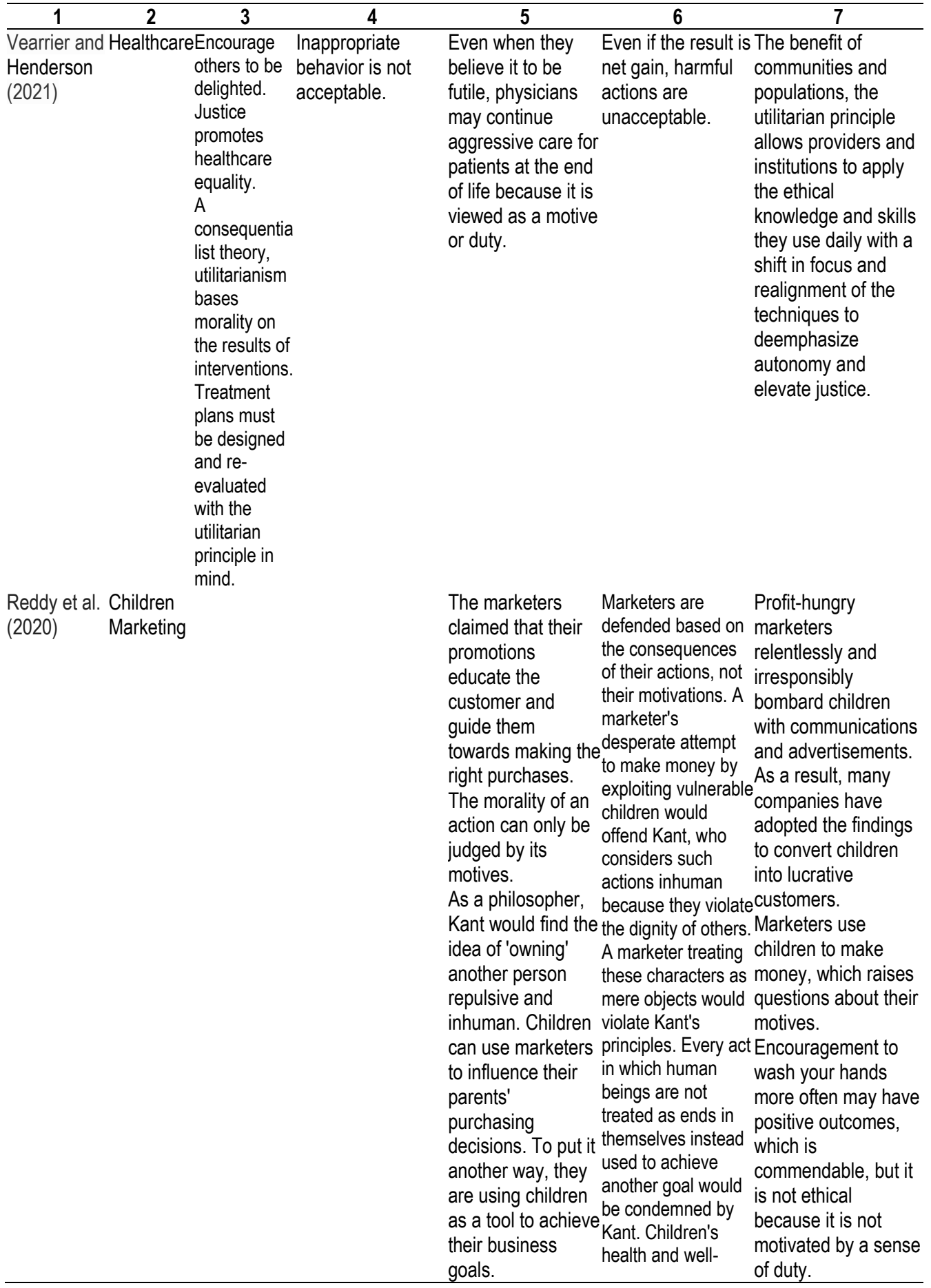


Continued Table 1

\begin{tabular}{|c|c|c|c|}
\hline 1 & 2 & 4 & 7 \\
\hline $\begin{array}{l}\text { Daniel and } \\
\text { Patrick } \\
\text { (2021). }\end{array}$ & $\begin{array}{l}\text { Child laborThe } \\
\text { utilitarian } \\
\text { ethic's ability } \\
\text { to quantify } \\
\text { cost-benefit } \\
\text { ratios needs } \\
\text { to be } \\
\text { corrected. } \\
\text { Kinder } \\
\text { beaten, } \\
\text { humiliated, } \\
\text { and } \\
\text { subjected to } \\
\text { psychologic } \\
\text { al abuse is } \\
\text { against all } \\
\text { humanitaria } \\
\text { n principles } \\
\text { (Kreikebaum } \\
\text {,2006; } \\
\text { Amnesty } \\
\text { International } \\
\text {, 2018). }\end{array}$ & $\begin{array}{l}\text { Since most child When people are } \\
\text { laborers are willing to work for } \\
\text { yunable to reach thethe benefit of their } \\
\text { age of } 50 \text { due to family, Kant says } \\
\text { permanent } \\
\text { damage to their acceptable } \\
\text { bodies and minds, (Kreikebaum, } \\
\text { violating children's 2006) } \\
\text { fundamental } \\
\text { human rights is } \\
\text { incompatible with } \\
\text { the concept of } \\
\text { social welfare } \\
\text { (Radfar et al., } \\
\text { 2018) }\end{array}$ & 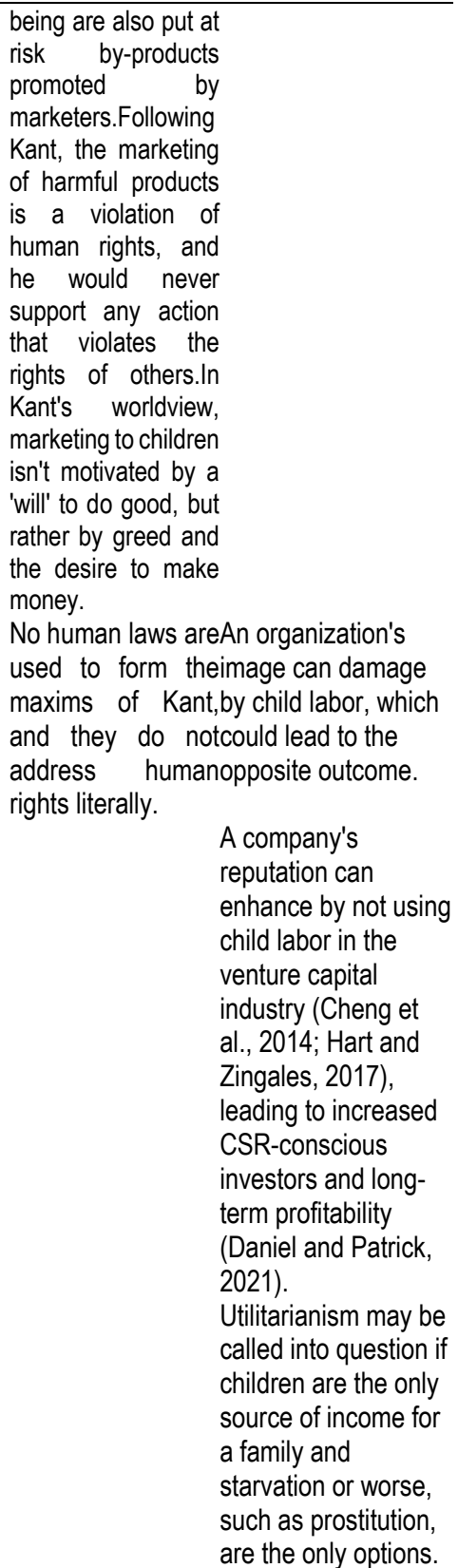 \\
\hline
\end{tabular}

Sources: developed by the authors.

Getting universal ethical standards is difficult because of the limitations of applying a universal ethical perception due to differences in relationship, culture, and customs. From a macro-environmental 
perspective, studies on ethical perception in the advertising business can be divided into 1) the legislative aspect of ethical perception, and 2) the ethical perception in the advertising industry, 3) the «social effect» aspect of advertising ethics «reliability» and "sincerity» related to empathy value expectations (EVE) and shared value expectations (SVE) in an environment that relies on social relationships and interactive media are examples of ethical conflicts related to culture in a multicultural, multi-religion coexistence system. According to a micro-practical perspective, studies on ethical perception in the advertising business could be divided into two categories: 1) advertisers, media, and advertising managers have ethical responsibilities, 2) from a marketing perspective, ethics to products children, adolescents, women, and the elderly are among the advertising targets that should consider ethically, and 3) communication ethics with appeal types/methods ethics based on consumer perception as a marketing communication agent, etc.

According to Kant's universal principles and the categorical imperative, the moral order related to duty relates to the philosophical aspect of the foundation. Deontology focuses on «righteousness» in the "process» of action rather than the result of the action. The categorical imperative has its foundation in universality and necessity and means absolute value understood by reason. Ethical values that encourage people to think and act per non-exclusive are absolute standards. According to Schlenker and Forsyth (1977), deontology-based moral value in advertising is the same context as idealism. These values, which take consumers as a goal and not just as a method, support opinions, and actions that strictly limit communication that deceives consumers or seeks unfair profits by exploiting their psychological traits. Deontology-based ethical values support the view that businesses' advertising actions are a method to achieve the commercial benefit, and those strict restrictions should apply. Advertising with gambling content should not be shown to children, teenagers, women, or people with poor judgment who need social protection. The legitimate pursuit of profit and ethical values by companies, advertising agencies, and media companies are sources of conflict during the COVID-19.

A consumer psychology perspective shows that utilitarian ethical values are related to the way consumers handle ethical dilemmas during decision-making processes. As a result of its primary focus on «mental happiness» and desirable «results», it is closely linked to consumer satisfaction of value expectations for interaction mediating media, integration of various media aiming to maximize communication utility, sharing meaning, and achieving goals using many media like utilizing one source multi-use, and so on to be sure, the utilitarianism-based ethical intention is not without its drawbacks: lack of clarity about who decides who is the majority, in a multicultural society, there is a possibility of collectivism and racism from cultures that have the strength and financial power, due to a lack of consideration for the goals of minority groups.

Actor-centered Aristotelian ethical value emphasizes practical ethical perception. According to Aristotle's ethical perspective, people's ultimate goal is good/happiness in a teleological worldview. Similarly, applying a good action concept to business marketing activities entails that, as the acting entities, they must exist as an organization that can fulfill good character to society, moving away from a business profit pursuer-centered position. Recent information producers using social networks from a media industry perspective can be applied. If considering the influence of interactive media on society and others, information creators must have a righteous character from an ethical view and must continuously execute this character.

Results. In 2013, the $7^{\text {th }}$ Amendment to the Cosmetics Directive 76/768/EEC announced a total marketing ban of products tested on animals. Products tested on animals outside the European Union cannot be sold within it. The Cosmetics Regulation 1223/2009/EC (which replaced Cosmetics Directive 76/768/EEC) was published by the European Union on July 11th, 2013 (European Commission, 2013). The requirements were bonded to the cosmetic manufacturers and distributors to ensure the smooth functioning and high level of protection of human health. Under Article 1 of EU Regulation 1223/2009, 
despite the law changes, consumer safety and the free circulation of cosmetic products remain the top priorities (Manteghi, 2017). When used under normal or reasonably foreseeable conditions, cosmetics must be safe for human health.

Case Study 1: Prohibited animal testing for cosmetics products in the European Union during COVID19. An individual's ability to predict the consequences of a purchasing decision of animal testing for cosmetic products is a vital aspect of utilitarian ethical theories. Utilitarianism is a correct moral choice that benefits the most people (Adekoya and Jimoh, 2019) during the COVID-19 crisis. In this case study, the rule utilitarianism also considers the law and fairness (Adekoya and Jimoh, 2019) because animal testing cosmetic products even cosmetics advertising are highly prohibited in the European Union (Manteghi, 2017). But Kantian principles proved that Europeans continue their attempts through sustaining cosmetic industry efforts to reduce environmental footprints and improve public health (Cosmetics Europe, 2014), which make a great European cosmetics industry remains a global leader because of the industry's significant investment in scientific research and development, innovative methods of cosmetics production, and expansion into new world markets, this has occurred. More than that, multinationals or small and medium-sized enterprises actively contribute to the industry's prosperity and continuously supply the consumer with high-quality everyday products and strive to meet all current requirements. As a result of regulatory harmonization and the removal of trade barriers, the European cosmetics industry intends to foster and promote a better trade environment for cosmetic products in Europe.

Case Study 2: European Cosmetics Advertising. There are over 4,000 small and medium-sized enterprises (SMEs) in Europe, and export is a primary activity for all sizes of companies, especially SMEs. Germany, France, the United Kingdom, Italy, and Spain are the top five countries that sell cosmetics, both domestically and internationally. Cosmetic companies such as Unilever (UK), L'Oreal, and Beiersdorf are the largest in Europe (CTPA, 2014).

During this COVID-19 crisis, European people still used cosmetics to protect their skin and hair from harmful environmental factors in modern society. Moreover, ultraviolet light and pollutants pose a significant threat to human health today. Cosmetics are also used for personal hygiene, to enhance attractiveness, to prevent aging, and to help people have a better time in their lives (Mitsui, 1993). Numerous studies and surveys (Sebnl, 2014) have shown that cosmetics could improve self-esteem, promote tranquility, and make people feel complete and confident. As shown in this case study, cosmetics advertising have influenced Europeans to choose carefully which cosmetics to use and which products to use in their daily life. The Utilitarian concept is regulated at the European level to ensure consumer safety and create a cosmetics market within the European Union (EU). Using healthy cosmetics products to enhance and protect human rights and happiness while avoiding harmful ones is the goal of the Utilitarian and Kantian perspectives on cosmetics advertising. It aims to reduce consumer concerns about the potentially negative effects of cosmetics advertising (Cosmetics Europe, 2012). As a result of Cosmetics Europe's commitment to fairness and honesty in advertising, consumers can make informed decisions and purchase products that meet their needs and wants. Since advertising and marketing communications businesses should not manipulate consumers without their knowledge and truthfulness, which is acceptable from a Kantian point of view.

Nevertheless, Kant's view stated that there should be no appearance of condoning or inciting violent, unlawful, and anti-social behavior in cosmetics advertising and marketing communication. When advertising cosmetics for children and young people, the guidelines state: «Do not use bodies or parts of bodies as objects when they are unrelated to the advertised product». Advertising cosmetics for children and young people should not encourage them to overuse such products and adverts. So, achieving global acceptance of the principle of self-regulation in cosmetic advertising is required by Europeans. Selfregulation effectively protects consumers while allowing innovation and competition (Gallon, 2014) during the COVID-19 pandemic. 
Case study 3: Malaysian Halal Advertising Cosmetics Products. Health and beauty products are one of Malaysia's fastest-growing industries. The Malaysian Communications and Multimedia Commission (MCMC), the Ministry of Health Malaysia, and the Department of Islamic Development (JKIM) have all issued guidelines for advertisers to follow when advertising their products on social media (JAKIM). Advertising is a form of business communication that aims to influence an audience to buy a product (Krithika, 2015). Due to creating a consequentialist perspective, Halal and Haram (Ozdemir and Yayl, 2014) were applied.

In addition to being a part of the brand and product, halal is also a crucial component for a conviction framework and ethical set of accepted rules (Wilson and Liu, 2010). When it comes to consumer purchasing behavior, it means selecting, purchasing, and consuming goods to satisfy their needs (Ramya and Ali, 2016). Anandarajan and Sivagami (2016) proposed that consumer purchasing behavior encompasses all of a customer's attitudes towards a product while their preferences, intentions, and decisions in the marketplace. From a Utilitarian and Kantian perspective, halal advertising cosmetics products are essential to consumers' ethical purchasing decisions. In addition to the idea of Halal, Halal advertising, and Islamic publicizing, the advertisements that have a culture-making and plan-making effect are also included as an ethical element. Despite this, it is safe to assume that the concept of Halal will not lose its importance and value in cosmetics products (Hoque et al., 2020). Similarly, it was explained that halal cosmetic well-being products are construed as securing users from using prohibited products by Shariah (Hashim and Mat Hashim, 2013; Mohezar et al., 2016).

Conclusion. One of the leading ethical theories is «utilitarianism», which says that moral decisions and actions should act based on consequences during the COVID-19. Advertising is closely related to the consumer decision-making process in purchasing cosmetic products. It is probably the most visible element of marketing strategies. Effective cosmetology advertising will elicit attention that helps consumers process information to evoke a positive attitude and buy the advertised cosmetic products. There are three measures of the consumers' purchasing behavior towards advertising, i.e., evaluating, considering, and taking the action of purchasing a product or not buying a product if it is not harmful to the health. Perhaps, utilitarianism indicated that first-time buyers would cease to exist in circles of dissatisfaction. Those who are satisfied are more likely to purchase the product again and develop brand loyalty for a specific product in the long run because it causes the human act in making moral decisions when purchasing the products.

Immanuel Kant, a philosopher from the eighteenth century, said that ethical behavior is guided by «categorical imperatives». Everybody should act as if their behavior could be the basis for universal laws of human behavior. Cosmetological advertising is said to affect a person's memory of a product. Thus, the advertisement could influence consumers' belief in the advertised product. Citizens should wonder what would happen if each customer had a cosmetic item that did not guarantee health due to inaccurate advertising and did not receive approval from the health ministry during COVID-19? Consequently, it should stand to reason that the entire advertising function is tightly regulated and monitored. The distinction between ethical practice and theories is also the clearest in this area.

During this COVID-19 pandemic, cosmetology advertising has a strong delivery capability and influence because it can provide useful information for the consumer in making a purchasing decision. As a consequence of this pandemic, utilitarianism and Kantian theory were used to identify the proper reason for using healthy cosmetic products without harming or affecting ethical human behavior and human decision-making. When it comes to purchasing a beauty product, the ethical theories suggest that the focus on advertising and interest in the products are the driving factors. Thus for the advertising designer, the creativity of an advertisement must facilitate to attract the consumer's attention with a high focus on a product before it can attract interest and influence the purchase behavior on the product. In the end, 
cosmetology advertising for environmentally friendly products has reopened the debate on advertising business ethics by connecting it to the Utilitarian and Kantian theory in recent years.

Last but not least, as a part of this review, the advertising industry should accept Aristotelian ethical values selectively and flexibly. Promote virtue and synergistic value in advertising. There are many ways to achieve harmony and balance among consumers, advertisers, media, agencies, regulatory agencies, and society.

Author Contributions: conceptualization, H. V. and I. A.; methodology, H. V.; formal analysis, H. V. and I. A.; investigation, H. V. and I. A.; resources, H. V.; writing-original draft preparation, H. V. and I. A.; writing-review and editing, H. V. and I. A.; visualization, H. V. and I. A.; supervision, H. V. and I. A.; project administration, H. V. and I. A.

Funding: This research received no external funding

\section{References}

Abdullahi, S. I. (2018). Measuring consumer perception of ethical issues in advertising: evidence from Nigerian advertising audience. Middle East Journal of Management, 5(3), 191-206. [Google Scholar]

Adekoya, O. D., \& Jimoh, I. (2019). An investigative role of ethics in business performance: The cas of McDonald's corporation in the United States of America and other Selected Countries. Scholars Journal of Economics, Business and Management, 6(3), 214-230. [Google Scholar] [CrossRef]

Al Mamun, A., Mohamad, M. R., Yaacob, M. R. B., \& Mohiuddin, M. (2018). Intention and behavior towards green consumption among low-income households. Journal of environmental management, 227, 73-86. [Google Scholar] [CrossRef]

Amaro, S., \& Duarte, P. (2015). An integrative model of consumers' intentions to purchase travel online. Tourism management, 46, 64-79. [Google Scholar] [CrossRef]

Amnesty International. (2018) Amnesty International Report 2017/2018-The State of the Worlds Human Rights. Retrieved from [Link]

Anandarajan, S. \& Sivagami, T. (2016). Consumer purchase decision behaviour towards cosmetics marketing. Asia Pacific Journal of Research, 1(37), 144-149. [Google Scholar]

Anjana, S. S. (2018). A study on factors influencing cosmetic buying behavior of consumers. International Journal of Pure and Applied Mathematics, 118(9), 453-459. [Google Scholar]

Arendt, C., LaFleche, M., \& Limperopulos, M. A. (2017). A qualitative meta-analysis of apologia, image repair, and crisis communication: Implications for theory and practice. Public Relations Review, 43(3), 517-526. [Google Scholar] [CrossRef]

Bakar, A., Lee, R., \& Hashim, N. H. (2013). Parsing religiosity, guilt and materialism on consumer ethics. Journal of Islamic Marketing, 4(3), 232. [Google Scholar] [CrossRef]

Cheng, B., loannou, I., \& Serafeim, G. (2014). Corporate social responsibility and access to finance. Strategic management journal, 35(1), 1-23. [Google Scholar] [CrossRef]

Chiu, C. M., Wang, E. T., Fang, Y. H., \& Huang, H. Y. (2014). Understanding customers' repeat purchase intentions in B2C ecommerce: the roles of utilitarian value, hedonic value and perceived risk. Information Systems Journal, 24(1), 85-114. [Google Scholar] [CrossRef]

Chonko, L. (2015). Ethical theories. Journal of Personal Selling and Sales Management, 35(2), 91-92. [Google Scholar]

Cosmetics Europe. (2012). Guiding principles on responsible advertising and marketing communication. Charter on Responsible Advertising and Marketing Communication. Retrieved from [Link]

Cosmetics Europe. (2014). Sustainability for a successful future. Retrieved from [Link]

CTPA. (2014). EU \& worldwide. Retrieved from [Link]

Dahlen, M. (2021). It's Time for TGA: Truly Good Advertising. Journal of Current Issues \& Research in Advertising, 42(2), 123-

131. [Google Scholar] [CrossRef]

Daniel, K., \& Patrick, S. (2021). Child Labour Ethics through the Prism of Utilitarianism and Deontology. Open Access Library Journal, 8(2), 1-14. [Google Scholar] [CrossRef]

De Blasio, G. (2008). Understanding McDonald's Among the «World's Most Ethical Companies». Electronic Journal of Business Ethics and Organization Studies, 13(1). [Google Scholar]

European Comission. (2013). Full EU ban on animal testing for cosmetics enters into force. Brussels. Press reliase database. Retrieved from [Link]

Fardouly, J., Pinkus, R. T., \& Vartanian, L. R. (2017). The impact of appearance comparisons made through social media, traditional media, and in person in women's everyday lives. Body image, 20, 31-39. [Google Scholar] [CrossRef]

Gai, J. (2020). Contextualized consumers: Theories and evidence on consumer ethics, product recommendations, and selfcontrol (No. EPS-2020-498-MKT). [Google Scholar] 
Gallon, V. (2014). Premium beauty news. Retrieved from [Link]

Global Insight. (2007). A study of the European Cosmetics Industry. Retrieved from [Link]

Gordiyevskaya, A. (2020). Ethics in digital marketing. Unpublished thesis. Lab University of Applied Sciences Ltd. Retrieved from [Link]

Hackley, C., \& Hackley, R. A. (2021). Advertising and promotion. Sage. [Google Scholar]

Halim, F., Ahmad, Z., Azmi, N. J., \& Omar, N. A. M. (2020). An analysis of puffery in advertising slogans. International Journal of Academic Research in Business and Social Sciences, 10(7), 626- 631. [Google Scholar]

Hart, O., \& Zingales, L. (2017). Companies should maximize shareholder welfare not market value. ECGI-Finance Working Paper, (521). [Google Scholar] [CrossRef]

Hashim, P., \& Mat Hashim, D. (2013). A review of cosmetic and personal care products: Halal perspective and detection of ingredient. Pertanika Journals of Science and Technology, 21(2), 281-292. [Google Scholar]

Hoque, M. O., Nayeem, A. R., Kamruzzaman, M., Ahmad, M. N., Abdullah, W. N. W. \& Akter, M. F. (2020). The impact of hala (Islamic) advertisement in YouTube on Malaysian rich food international brands. International Journal of Publication and Social Studies, 5(2), 189-197. [Google Scholar]

Jun, S. H. (2020). The effects of perceived risk, brand credibility and past experience on purchase intention in the Airbnb context. Sustainability, 12(12), 5212. [Google Scholar] [CrossRef]

Kant, I. (1999). Practical philosophy. Cambridge University Press. [Google Scholar]

Kant, I., \& Wood, A. (2009). Groundwork for the Metaphysics of Morals. Yale University Press. [Google Scholar]

Khattri, V. (2019). Impact of cosmetic advertisements on women. CASS, 3(1), 305-330. Retrieved from [Link]

Kim, E., \& Ham, S. (2017). Development and validation of a measure of consumer behaviors toward nutritional labeling in restaurants. Journal of foodservice business research, 20(5), 595-610. [Google Scholar] [CrossRef]

Kim, J., \& Kim, C. (2017). Three Perspectives about Ethical Value in Advertising Business. International Journal of Journalism and Mass Communication, 4(1), 124. [Google Scholar]

Koch, J., Frommeyer, B., \& Schewe, G. (2020). Online shopping motives during the COVID-19 pandemic-lessons from the crisis. Sustainability, 12(24), 10247. [Google Scholar] [CrossRef]

Kreikebaum, H. (2006) Internationale Unternehmensethik. In: Albach, H., Ed., Unternehmensethik und globale Märkte Zeitschrift für Betriebswirtschaft Special issue, Gabler, Wiesbaden. [Google Scholar]

Krithika, M. R. (2015). The impact of cosmetic advertisements in Television: A study among college girl students' self-esteem and beauty. Journal for Studies in Management and Planning, 1(3), 228-244.

Loxton, M., Truskett, R., Scarf, B., Sindone, L., Baldry, G., \& Zhao, Y. (2020). Consumer behaviour during crises: preliminary research on how coronavirus has manifested consumer panic buying, herd mentality, changing discretionary spending and the role of the media in influencing behaviour. Journal of risk and financial management, 13(8), 166. [Google Scholarl [CrossRef]

Manteghi, M. (2017). European Cosmetics Industry: Main Aspects and Regulation. Available at SSRN 3082290. [Google Scholar]

Martin, R., Kusev, P., Teal, J., Baranova, V., \& Rigal, B. (2021). Moral Decision Making: From Bentham to Veil of Ignorance via Perspective Taking Accessibility. Behavioral Sciences, 11(5), 66. [Google Scholar] [CrossRef]

Mensah, R. O. (2020). A comparative philosophical analysis of the Kantian principle of moral theory and the Utilitarian theory: Applications and critiques. Journal of Humanities and Social Sciences, 3(3), 127-131. [Google Scholar]

Mitsui, T. (1993). New Cosmetic Science, (Ed). Elsevier. [Google Scholar]

Mohamed Azmi, A. H., \& Sadia, S. (2020). Pharmaceutical and cosmeceutical marketing and advertising in Malaysia: An overview of current governing laws and regulations. Biomedical Journal of Science \& Technical Research, 26(3), 19997-20006. Retrieved from [Link]

Mohezar, S., Zailani, S., \& Zainuddin, Z. (2016). Halal cosmetics adoption among young Muslim consumers in Malaysia: Religiosity concern. Global Journal Al-Thaqafah, 6(1), 47-59. [Google Scholar]

Nejati, M. \& Moghaddam, P. P. (2013). The effect of hedonic and utilitarian values on satisfaction and behavioural intentions for dining in fast-casual restaurants in Iran. British Food Journal, 115(11), 1583-1596. [Google Scholar] [CrossRef]

Nuseir, M. T. (2018). Impact of misleading/false advertisement to consumer behaviour. International Journal of Economics and Business Research, 16(4), 453-465. [Google Scholar]

Olatunji, T. E. (2013). The impact of accounting system on the performance of small and medium scale enterprises in Nigeriaa survey of SMEs in Oyo State-Nigeria. International journal of business and management invention, 2(9), 13-17. [Google Scholar] Ozdemir, H., \& Yayli, A. (2014). A study on the preferences consumers' of halal-certified products: A case study of Istanbul. Journal of Business Research, 6(1), 183-202. Retrieved from [Link]

Podrez, E. (2017). Socrates and Business Ethics Considerations on the ethical origins of responsibility. Annales. Etyka w Życiu Gospodarczym, 20(8), 7-18. [Google Scholar]

Radfar, A., Asgharzadeh, S. A. A., Quesada, F., \& Filip, I. (2018). Challenges and perspectives of child labor. Industrial psychiatry journal, 27(1), 17. [Google Scholar] [CrossRef]

Ramya, N., \& Ali, S. M. (2016). Factors affecting consumer buying behavior. International journal of applied research, 2(10), 76-80. [Google Scholar] 
Rani, N. S. A., \& Krishnan, K. S. D. (2018). Factors that influence Malay students in purchasing skincare products in Malaysia. Journal of Business and Retail Management Research, 13(1). [Google Scholar]

Rautenbach, G., \& Keet, C. M. (2020). Toward equipping Artificial Moral Agents with multiple ethical theories. [Google Scholar] Reddy, T. R., Reddy, D. E. L., \& Reddy, T. N. (2020). Examining the Ethics of Marketing to Children From a Kantian Perspective. Journal of Social and Political Sciences, 3(4). [Google Scholar]

Robinson, R., \& Shah, N. (2019). Business' environmental obligations and reasoned public discourse: A Kantian foundation for analysis. Journal of Business Ethics, 159(4), 1181-1198. [Google Scholar] [CrossRef]

Rosenbaum-Elliott, R. (2021). Strategic advertising management. Oxford University Press. [Google Scholar]

Sasa, M. S. (2019). An Appraisal of the Concept of Beauty in Immanuel Kant's Philosophy. GNOSI: An Interdisciplinary Journal of Human Theory and Praxis, 2(2), 87-97. [Google Scholar]

Savulescu, J., Persson, I., \& Wilkinson, D. (2020). Utilitarianism and the pandemic. Bioethics, 34(6), 620-632. [Google Scholar] [CrossRef]

Scarre, G. (2020). Utilitarianism. Routledge. [Google Scholar]

Schlenker, B. R., \& Forsyth, D. R. (1977). On the ethics of psychological research. Journal of Experimental Social Psychology, 13(4), 369-396. [Google Scholar] [CrossRef]

Sebnl. (2014). The importance of cosmetics and make up. Retrieved from [Link]

Skov, M., \& Nadal, M. (2021). The nature of beauty: behavior, cognition, and neurobiology. Annals of the New York Academy of Sciences, 1488(1), 44-55. [Google Scholar]

Soesilo, P. K., Gunadi, W., \& Arimbi, I. R. (2020). The effect of endorser and corporate credibility on perceived risk and consumer confidence: The case of technologically complex products. Journal of Marketing Communications, 26(5), 528-548. [Google Scholar] Sripathi, M. (2020). A study on impact of false advertising on the consumer buying behaviour. Journal of Interdisciplinary Cycle Research, 12(9), 1066- 1074. [Google Scholar]

Thew, M. (2017). Etonogestrel implant-to leave or stay: A case series. Global pediatric health, 4. [Google Scholar] [CrossRef] Ulgen, O. (2017). Kantian ethics in the age of artificial intelligence and robotics. QIL, 43, 59-83. [Google Scholar]

Vearrier, L., \& Henderson, C. M. (2021, June). Utilitarian principlism as a framework for crisis healthcare ethics. In Hec Forum (Vol. 33, No. 1, pp. 45-60). Springer Netherlands. [Google Scholar] [CrossRef]

Wang, Y., Zhao, Y., \& Song, F. (2020). The ethical issues of animal testing in cosmetics industry. Humanities and Social Sciences, 8(4), 112. [Google Scholar]

Wilson, J. A., \& Liu, J. (2010). Shaping the Halal into a brand?. Journal of Islamic Marketing, 1(2), 107-123. [Google Scholar] [CrossRef]

$\mathrm{Xu}, \mathrm{J}$. (2020). Unintended effects of advertising: An updated qualitative review. Review of Communication Research, 8, 1-16. [Google Scholar] [CrossRef]

Yang, Y., Li, O., Peng, X., \& Wang, L. (2020). Consumption trends during the COVID-19 crisis: How awe, coping, and social norms drive utilitarian purchases. Frontiers in psychology, 11, 2695. [Google Scholar] [CrossRef]

Yıldırım, M., \& Güler, A. (2020). Factor analysis of the COVID-19 perceived risk scale: A preliminary study. Death Studies, 1-8. [Google Scholar] [CrossRef]

Хамлошіні Васудеван, Dr.Sc., Міжнародний університет Inti, Малайзія

Імран Аслан, доцент, Університет Бінгеля, Туреччина

Промоція косметичної продукції: використання етичних теорій в умовах COVID-19

Статтю присвячено аналізу маркетингових підходів промоції косметологічної продукції під час COVID-19 з погляду теорії утилітаризму і кантіанства. Встановлено, що однією з причин поширення негативних наслідків впливу COVID-19є нехтування населенням країн питань етики та рівноправності. Неспроможність виявити етичні проблеми впровадження відповідних заходів попередження COVID-19 спричинила масову втрату людських життів. У роботі висунута гіпотеза про необхідність врахування етичних та моральних особливостей залучення людей до споживання продуктів, що є корисними для здоров'я з при формуванні плану заходів з зменшення негативного впливу COVID-19. Встановлено, що утилітаризм та кантіанство $€$ найбільш популярними етичними теоріями, в яких викладені чіткі та дієві принципи поведінки споживачів. Обгрунтовано напрями промоції косметологічної продукції з теорії з погляду теорії утилітаризму, які можуть сприяти підвищенню споживання косметичних засобів та зниженню негативного впливу на здоров'я населення COVID-19. На прикладі реклами косметичних товарів країн Європи та Азії, встановлено, що теорії утилітаризму та кантіанства мали позитивний вплив на споживачів під час COVID-19. У ході дослідження авторами доведено, що досліджувані теорії найбільш ефективно сприяли визначенню цінності та вартості косметичних товарів суспільством. Однак, авторами зазначено, що перш, ніш прийняти теорію утилітаризму чи кантіанства, суспільство повинно мати чітке розуміння, якими є переваги означених теорій в промоції товарів. Результати дослідження дають підстави стверджувати, що для забезпечення дотримання етичних стандартів при розробленні нових та інноваційних маркетингових стратегій, тактик та практик в умовах пандемії COVID-19, необхідно застосовувати етичні теорії у всіх сферах. Крім цього, маркетингові агенції повинні використовувати аристотелівські етичні цінності при формуванні рекламних кампаній.

Ключові слова: реклама косметики, COVID-19, косметичний продукт, теорія утилітаризму, теорія кантіанства 